\title{
PERAN PROBLEM FOCUSED COPING DAN KONSEP DIRI TERHADAP PENYESUAIAN DIRI PADA REMAJA AKHIR YANG MENJADI PENGURUS ORGANISASI KEMAHASISWAAN DI FAKULTAS KEDOKTERAN UNIVERSITAS UDAYANA
}

\author{
Sang Ayu Ketut Tri Semaraputri dan I Made Rustika \\ Program Studi Psikologi, Fakultas Kedokteran, Universitas Udayana \\ semaraputri6@gmail.com
}

\begin{abstract}
Abstrak
Pada mahasiswa yang menjadi pengurus organisasi, dibutuhkan penyesuaian diri yang baik agar tercapai keseimbangan antara bidang akademik dengan organisasi. Tantangan yang dihadapi ketika melakukan penyesuaian diri adalah banyaknya hal baru yang harus disesuaikan secara bersamaan. Penyesuaian diri merupakan proses yang berlangsung secara terus-menerus sepanjang hidup individu. Aspek mental ini tidak dibawa sejak lahir, melainkan terbentuk karena banyak faktor. Penggunaan strategi problem focused coping memengaruhi individu untuk berfokus pada masalah sehingga penyelesaian masalah dapat dilakukan dengan baik dan terarah, hal ini berkontribusi terhadap penyesuaian diri yang baik. Konsep diri yang positif memengaruhi penyesuaian diri yang baik karena individu mengetahui tentang dirinya sehingga mampu mencapai keharmonisan antara diri dengan lingkungan. Tujuan penelitian ini adalah untuk mengetahui peran problem focused coping dan konsep diri terhadap penyesuaian diri pada remaja akhir. Subjek dalam penelitian ini adalah 150 orang mahasiswa Fakultas Kedokteran Universitas Udayana angkatan 2015 yang menjadi pengurus organisasi kemahasiswaan di Fakultas Kedokteran Universitas Udayana. Instrumen penelitian ini adalah skala problem focused coping, skala konsep diri, dan skala penyesuaian diri. Hasil uji regresi berganda menghasilkan nilai $\mathrm{R}$ sebesar $0,728(\mathrm{~F}=82.876$; $\mathrm{p}<0,05)$ yang berarti problem focused coping dan konsep diri secara bersama-sama berperan terhadap penyesuaian diri. Koefisien determinasi yang dihasilkan sebesar 0,530 yang berarti problem focused coping dan konsep diri secara bersama-sama memiliki sumbangan efektif sebesar $53 \%$ terhadap penyesuaian diri. Problem focused coping memiliki nilai koefisien beta terstandarisasi sebesar 0,477 (t= $7,634 ; \mathrm{p}<0,05)$ yang berarti problem focused coping memiliki peran yang siginifikan terhadap penyesuaian diri. Konsep diri memiliki nilai koefisien beta terstandarisasi sebesar 0,382 $(t=6,099 ; \mathrm{p}<0,05)$ yang berarti konsep diri memiliki peran yang signifikan terhadap penyesuaian diri.
\end{abstract}

Kata Kunci: Problem focused coping, konsep diri, penyesuaian diri, remaja akhir

\begin{abstract}
Student who became an administrator of student organization need a well self-adjustment so academics and organization can be harmony. The challenges is student who became an administrator of student organization had to adjust a lot of new things at the same time. Self-adjustment is a process that occur continuously through the human life. That aspect not carried be born, but are formed due many factors. Problem focused coping strategy predispose human to focus on solving a problem that can be well and directional, this contributing to a well self-adjustment. Positive self-concept predispose well self-adjustment because human know who they are to achieve harmonization between them self and environment. The purpose of this research to know the role of problem focused coping and self-concept toward self-adjustment of late adolescent. The subject of this research are 150 students in Faculty of Medicine Udayana University 2015 generation who became an administrator of student organization in Faculty of Medicine Udayana University. The instrument in this research are problem focused coping scale, self-concept scale, and self-adjustment scale. The result of multiple regression test show the coefficient of $\mathrm{R}$ is $0,728((\mathrm{~F}=82.876$; $\mathrm{p}<0,05)$ so it can be mentioned that problem focused coping and self-concept are conjunctly contributes to selfadjustment. Determination coefficient is 0,530 it means problem focused coping and self-concept are conjunctly contributes as much as $53 \%$ to self-adjustment. Standardized Beta coefficient of problem focused coping is 0,477 $(\mathrm{t}=$ $7,634 ; \mathrm{p}<0,05)$ which conclude that problem focused coping is contribute to self-adjustment. Standardized Beta coefficient of self-concept is $0,382(t=6,099 ; \mathrm{p}<0,05)$ which conclude that self-concept is contribute to selfadjustment.
\end{abstract}

Keyword: Problem focused coping, self-concept, self-adjustment, late adolescent 


\section{LATAR BELAKANG}

Sebagai makhluk sosial, manusia dalam kehidupan sehari-hari hidup berdampingan dengan manusia lainnya. Manusia melakukan interaksi dan menjalin hubungan dengan lingkungan sekitar sebagai bentuk pemenuhan kebutuhan, harapan dan tuntutan dalam diri. Pemenuhan kebutuhan diri individu terhadap tuntutan lingkungan sekitar dapat dilakukan dengan melakukan penyesuaian diri.

Menurut Schneiders (1964) penyesuaian diri merupakan suatu proses yang mencakup respon mental dan tingkah laku individu sebagai usaha dalam menghadapi stres, frustrasi, dan konflik terhadap tuntutan lingkungan dimana individu berada. Penyesuaian diri dapat berarti sebagai suatu bentuk reduksi untuk tekanan dari kebutuhan individu, kemampuan dalam "berdamai" dengan kekecewaan yang dialami, perkembangan dari mekanisme psikologis, atau merupakan pola yang diadaptasi dari perilaku yang sesuai dengan berbagai situasi.

Bagi beberapa orang, penyesuaian diri juga dapat dijadikan sebagai bentuk dari resolusi konflik, sehingga pada akhirnya berhasil hidup bersama-sama dengan individu lainnya. Penyesuaian diri ini dapat menentukan bagaimana seseorang bertahan dalam suatu kondisi, sehingga tetap berfungsi dengan baik di lingkungan. Dari definisi tersebut, secara tidak langsung menekankan pada peran aktif dari individu sendiri akan memengaruhi bagaimana penyesuaian diri individu. Kebutuhan untuk memenuhi tuntutan lingkungan dicapai dengan mengubah tingkah laku, sampai akhirnya ditemukan reaksi yang dapat memberikan kepuasan.

Schneiders (1962) mengemukakan, individu dengan penyesuaian diri yang baik adalah individu yang merespon secara matang, efisien, memuaskan dan sehat. Efisien yang dimaksud adalah kepuasan tanpa terlalu banyak mengeluarkan energi, menguras waktu atau kesalah-kesalahan lainnya. Sedangkan sehat yang dimaksud adalah respon penyesuaian sesuai dengan kondisi alami dari individu, sesuai dengan hubungan individu dengan lingkungan, dan sesuai dengan hubungan individu dengan Tuhan-nya. Individu dengan penyesuaian diri yang baik juga relatif bebas dari simtomsimtom yang mengganggu keberfungsian individu seperti kecemasan kronis, ketakutan, obsesi, phobia, keberatan, keraguan, dan atau sejenisnya.

Selain sebagai salah satu cara untuk memenuhi kebutuhan akan tantangan hidup, penyesuaian diri juga penting bagi individu sebagai bentuk usaha untuk survive di lingkungan. Penyesuaian diri disesuaikan dengan konteks permasalahan yang dihadapi dan tetap memperhatikan tahap perkembangan. Penyesuaian diri yang baik di setiap tahap perkembangan akan memengaruhi individu dalam mengahadapi tahap perkembangan selanjutnya. Hal tersebut menjadikan individu akan selalu melakukan penyesuaian diri sepanjang rentang kehidupan terlebih lagi pada masa remaja.
Masa remaja adalah masa peralihan dari dunia anakanak menuju masa dewasa. Banyak orang mengatakan bahwa masa remaja ini adalah masa pencarian jati diri. Pertanyaan "Siapa saya?" pada masa remaja menjadi penting. Remaja akan semakin menjauhkan diri dari orang tua dan semakin mendekati kelompok sebaya untuk menjawab pertanyaan tersebut (Santrock, 2007).

Periode perkembangan masa remaja dimulai dengan pubertas. Slavin (2011) menyatakan periode pubertas yang terjadi saat masa remaja awal (10 atau 13 tahun sampai 17 tahun) adalah waktu dimana terjadinya perkembangan fisik dan intelektual yang pesat. Sedangkan masa remaja akhir (17 tahun sampai 22 tahun) adalah periode penyesuaian diri dan pengintegrasian perubahan masa remaja awal yang lebih stabil. Masa remaja akhir ditandai dengan peralihan tanggung jawab, pilihan dan kesempatan masa dewasa.

Menurut teori perkembangan psikososial Erikson (dalam Santrock, 2007), terdapat delapan tahap perkembangan sepanjang kehidupan. Setiap tahap terdiri dari tugas perkembangan yang unik dan menghadapkan seseorang pada suatu krisis yang harus dipecahkan. Pada masa remaja terjadi konflik psikososial yaitu identity versus identity confusion. Pada tahap ini individu dihadapkan pada penemuan diri, tentang siapa diri sebenarnya, dan kemana akan melangkah dalam hidup ini. Ketika konflik tersebut tidak dapat terselesaikan karena misalkan orangtua terlalu memaksakan kehendak pada anak remaja, remaja menjadi tidak cukup dalam menjelajahi banyak peran, dan jika masa depan positif belum jelas, maka terjadilah kebingungan identitas.

Masa remaja dialami saat duduk di bangku sekolah, hal ini menjadikan waktu remaja sebagian besar dihabiskan dengan kegiatan belajar mengajar dan bergaul dengan sebaya di sekolah. Ketika individu berkembang dari masa anak-anak menjadi remaja, kemudian berkembang lagi menjadi orang dewasa, individu akan mengalami transisi di masa sekolah. Masing-masing tahapan transisi yang dilalui memberikan dampak bagi remaja, salah satu dampak yang terjadi adalah stres (Eccles, 2004; Eccles \& Wigfield, 2000; Hawkins \& Berndt, 1985; Wigfield, dkk, 2006 dalam Santrock, 2007).

Begitu juga dalam masa transisi dari masa sekolah menegah atas ke perguruan tinggi. Perubahan posisi dari menjadi senior di sekolah menengah atas menjadi mahasiswa tingkat satu di perguruan tinggi mengulang fenomena top-dog pada remaja. Ketika mengalami fenomena top-dog, penyesuaian diri yang baik sangat dibutuhkan sebagai usaha ketika menghadapi kondisi stres dan konflik yang terjadi pada diri remaja karena tuntutan lingkungan dimana individu berada. Hasil penelitian Sasmita (2015) mengemukakan penyesuaian diri mahasiswa tahun pertama sangat penting karena akan menentukan bagaimana mahasiswa mampu menghadapi semester-semester selanjutnya. Dalam penyesuaian diri tersebut ada remaja yang mudah 
menyesuaikan diri dan ada yang sulit. Timbul pertanyaan mengapa ada remaja yang dapat menyesuaikan diri dengan baik dan ada yang sulit menyesuaikan diri.

Pada remaja akhir yang sudah menjadi mahasiswa, terlebih lagi menjadi pengurus organisasi, penyesuaian diri dalam kehidupan berorganisasi yang berbeda dengan mahasiswa yang tidak menjadi pengurus organisasi tentu sangat penting untuk diperhatikan. Hal ini dikarenakan remaja akhir yang menjadi pengurus organisasi memiliki tanggungjawab yang lebih banyak, menghadapi masalah yang lebih beragam di luar masalah akademik, serta memiliki pandangan mengenai diri yang berbeda dengan remaja akhir yang tidak menjadi pengurus organisasi. Mahasiswa yang aktif berorganisasi memiliki nilai lebih dibandingkan mereka yang tidak aktif berorganisasi (Merdeka, 2016). Remaja akhir yang menjadi pengurus organisasi kemahasiswaan dituntut untuk mampu menyesuaikan diri dengan baik, dengan banyak hal yang harus disesuaikan secara bersamaan sehingga penyesuaian diri menjadi salah satu sumber permasalahan bagi remaja akhir yang menjadi pengurus organisasi kemahasiswaan (Semaraputri, 2016b). Pengurus organisasi yang tidak mampu mengharmoniskan diri dengan lingkungan akan memunculkan pola perilaku yang keliru (Zakiyah, Hidayati, \& Setyawan, 2010).

Berdasarkan hasil studi pendahuluan, penyesuaian diri merupakan salah satu hal yang menjadi masalah pada pengurus organisasi kemahasiswaan di tahun pertama masuk perguruan tinggi. Penyesuaian diri dengan kehidupan perguruan tinggi seperti tugas-tugas, dosen, teman di kelas, harus dilakukan bersamaan dengan penyesuaian diri di lingkungan organisasi kemahasiswaan seperti budaya organisasi kemahasiswaan serta teman-teman sesama pengurus organisasi yang berasal dari berbagai program studi dan dari angkatan yang berbeda (Semaraputri, 2016b).

Di Universitas Udayana, setiap fakultas memiliki organisasi kemahasiswaan dengan jumlah yang beragam. Jumlah organisasi kemahasiswaan di setiap fakultas di Universitas berdasarkan data dari BEM PM Udayana Kabinet Udayana Berintegritas, di Fakultas Ilmu Budaya terdapat 12 organisasi, di Fakultas Kedokteran terdapat 15 oragnisasi, di Fakultas Hukum terdapat 5 organisasi, di Fakultas Teknik terdapat 11 organisasi, di Fakultas Pertanian terdapat 3 organisasi, di Fakultas Ekonomi dan Bisnis terdapat 9 organisasi, di Fakultas Peternakan terdapat 2 organisasi, di Fakultas Matematika dan Ilmu Pengetahuan Alam terdapat 9 organisasi, di Fakultas Kedokteran Hewan terdapat 3 organisasi, di Fakultas Teknik Pertanian terdapat 5 organisasi, di Fakultas Pariwisata terdapat 2 organisasi, Fakultas Ilmu Sosial dan Ilmu Politik terdapat 9 organisasi, dan di Fakultas Kelautan dan Perikanan terdapat 2 organisasi. Fakultas Kedokteran Universitas Udayana menjadi fakultas di Universitas Udayana dengan jumlah organisasi terbanyak dan kegiatan kemahasiswaan yang lebih dari 150 kegiatan kemahasiswaan per tahun (Badan Eksekutif Mahasiswa Fakultas Kedokteran Universitas Udayana, 2016) sehingga membutuhkan peran dari banyak mahasiswa sebagai pengurus organisasi ataupun dalam kepanitiaan kegiatan kemahasiswaan.

Kesulitan menyesuaikan diri yang dialami pengurus organisasi yaitu kesulitan dalam hal manajemen waktu, kesulitan membuat skala prioritas antara tugas-tugas akademik dengan tanggungjawab di organisasi, serta kesulitan berinteraksi dengan sesama pengurus organisasi kemahasiswaan yang berasal dari program studi dan angkatan yang berbeda karena merasa canggung. Pada organisasi kemahasiswaan tingkat fakultas pengurus terdiri dari mahasiswa program studi dan angkatan yang berbeda, sedangkan pada organisasi kemahasiswaan tingkat program studi pengurus terdiri dari mahasiswa angkatan yang berbeda.

Permasalahan yang dihadapi pada akhirnya berdampak bagi salah satu bidang sehingga ada pengurus organisasi yang tidak maksimal ketika menjadi pengurus organisasi seperti tidak pernah berkontribusi pada kegiatankegiatan yang dilakukan oleh organisasi yang bersangkutan dan ada pengurus organisasi yang tidak maksimal di bidang akademik (Semaraputri, 2016a). Hal ini merupakan bentuk dari konsekuensi dari pilihan menjadi pengurus organisasi kemahasiswaan, mahasiswa membagi konsentrasi, waktu dan pemikiran menjadi dua yaitu di bidang akademik dan organisasi bahkan ada yang meninggalkan kegiatan akademik karena terlalu larut dalam kegiatan berorganisasi (Basuki, 2017). Hasil penelitian Setyono (2013) mengemukakan dampak negatif bagi mahasiswa yang aktif berorganisasi diantaranya sering terlambat dan membolos dalam mengikuti perkuliahan, prestasi akademik kurang baik bahkan cenderung menurun, dan sering kali tidak tepat waktu dalam menyelesaikan perkuliahan. Oleh karena itu dibutuhkan kemampuan penyesuaian diri yang baik pada remaja yang menjadi pengurus organisasi kemahasiswaan di Fakultas Kedokteran Universitas Udayana.

Kemampuan menyesuaikan diri sangat berkaitan dengan cara-cara mengatasi masalah. Pemilihan cara mengatasi masalah ini disebut dengan istilah proses coping. Menurut Lazarus (1969), coping dipandang sebagai faktor yang menentukan kemampuan manusia untuk melakukan penyesuaian terhadap situasi yang menekan (stressful life events). Menurut Silvana (2012) coping berasal dari kata to cope yang berarti mengatasi kesukaran atau usaha meniadakan atau membebaskan diri dari rasa tidak enak karena stres.

Menurut Santrock (2007) coping adalah upaya untuk mengelola situasi yang membebani, memperluas usaha untuk memecahkan masalah-masalah hidup dan berusaha mengatasi atau mengurangi stres. Coping adalah proses yang dialami individu berupa pemikiran dan tindakan atau perilaku- 
perilaku, dalan rangka mengatur atau mengelola ketidaksesuaian antara tuntutan-tuntutan dari suatu situasi dan sumber-sumber yang dimiliki individu, dalam menilai atau menghadapi kondisi stres (Taylor, 2009). Lazarus (1969) mengklasifikasikan coping menjadi dua bagian, yaitu problem focused coping dan emotional focused coping. Problem focused coping merupakan usaha yang dilakukan individu dengan cara menghadapi secara langsung sumber penyebab masalah.

Tipe problem focused coping biasanya digunakan oleh individu ketika mengalami gangguan, ancaman atau situasi yang menantang serta dapat berubah. Problem focused coping meliputi upaya untuk melakukan sesuatu yang konstruktif mengenai kondisi stressfull yang membahayakan, mengancam atau menantang individu. Kemampuan problem focused coping muncul selama masa kanak-kanak, sedangkan emotion focused coping muncul lebih lambat, masa kanakkanak akhir atau dewasa muda (Taylor, 2009). Secara khusus, terkadang individu menggunakan kedua strategi coping (problem focused dan emotional focused), disarankan agar kedua tipe coping digunakan oleh individu ketika menghadapi kondisi stressfull. Tipe coping yang digunakan juga disesuaikan dengan sumber permasalahan sehingga mampu menyelesaikan masalah dengan baik (Folkman \& Lazarus, 1984).

Menurut Schneiders (1964) salah satu ciri-ciri penyesuaian diri yang baik adalah individu dapat lebih objektif menerima keadaan diri dan mudah beradaptasi dengan kondisi baru. Terkait dengan penyesuaian diri, digunakannya metode problem focused coping dapat memengaruhi sikap realistis dan objektif individu dalam menghadapi permasalahan.

Hasil penelitian Bachtiar dan Asriani (2015) menunjukkan problem focused coping terbukti efektif meningkatkan pengelolaan stres pada remaja. Berdasarkan hasil penelitian dan pembahasan ada perbedaan yang signifikan antara pengelolan stres antara siswa yang menggunakan strategi Problem Focused Coping lebih dan Emotion Focused Coping, sehingga dapat disimpulkan bahwa strategi Problem Focused Coping lebih efektif dari pada Emotion Focused Coping dalam meningkatkan pengelolaan stres siswa di SMA Negeri 1 Barru. Jika stres dapat dikelola dengan baik, hal ini akan berpengaruh positif pada penyesuaian diri remaja.

Penyesuaian diri juga dipengaruhi oleh bagaimana individu dapat mengarahkan diri sendiri. Sebelum dapat mengarahkan diri sendiri, remaja tentu harus mengetahui bagaimana diri sendiri sehingga tahu arah mana yang akan dituju. Dalam hal ini konsep diri pada remaja memiliki peran. Dapat mengenali diri sendiri dengan mengetahui positif dan negatif dalam diri merupakan salah satu syarat dari terciptanya penyesuaian diri yang baik.
Konsep diri merujuk pada evaluasi yang menyangkut bidang-bidang tertentu dari diri (Santrock, 2007). Atwater (1983) menyebutkan bahwa konsep diri adalah keseluruhan gambaran diri, yang meliputi persepsi seseorang tentang diri, perasaan, keyakinan, dan nilai-nilai yang berhubungan dengan diri. Remaja melakukan evaluasi diri dalam berbagai bidang seperti bidang akademik, atletik, penampilan fisik, dan sebagainya. Remaja akan membentuk konsep diri sesuai dengan pengalaman-pengalaman yang telah dialami.

Konsep diri adalah penilaian remaja tentang diri sendiri yang bersifat fisik, psikis, sosial, emosional, aspirasi, dan prestasi. Konsep diri fisik adalah gambaran remaja tentang penampilan, arti penting tubuh dalam hubungan dengan perilakunya di mata orang lain. Konsep diri psikis adalah gambaran remaja tentang kemampuan dan ketidakmampuan, harga diri dan hubungan remaja dengan orang lain. Konsep diri sosial adalah gambaran remaja tentang hubungannya dengan orang lain, dengan teman sebaya, dengan keluarga, dan lain-lain. Konsep diri emosional adalah gambaran remaja tentang emosi diri, seperti kemampuan menahan emosi, pemarah, sedih, atau riang-gembira, pendendam, pemaaf, dan lain-lain. Konsep diri aspirasi adalah gambaran remaja tentang pendapat dan gagasan, kreativitas, dan cita-cita. Konsep diri prestasi adalah gambaran remaja tentang kemajuan dan keberhasilan yang akan diraih, baik dalam masalah belajar maupun kesuksesan hidup (Hurlock, 1980). Penelitian Gunarta (2015) mengenai konsep diri, dukungan sosial dan penyesuaian diri sosial mahasiswa pendatang di Bali menunjukkan bahwa terdapat hubungan positif antara konsep diri dengan penyesuaian diri sosial.

Konsep diri merupakan hal yang penting dalam kehidupan sebab pemahaman seseorang mengenai konsep dirinya akan menentukan dan mengarahkan perilaku dalam berbagai situasi. Hurlock (1980) menambahkan bahwasanya konsep diri individu dapat menentukan keberhasilan dan kegagalan seseorang dalam hubungannya dengan masyarakat. Hal tersebut berarti konsep diri yang positif memiliki hubungan positif terhadap penyesuaian diri remaja karena semakin positif pemahaman diri yang dimiliki, maka semakin diketahui tentang diri, dan kemudian mampu untuk mengarahkan diri sehingga penyesuaian diri semakin baik.

Berdasarkan uraian diatas, terlihat bahwa problem focused coping dan konsep diri dapat berperan dalam memengaruhi taraf penyesuaian diri seseorang. Oleh karena itu melalui penelitian ini ingin diketahui bagaimana peran salah satu strategi coping yaitu problem focused coping dan konsep diri terhadap penyesuaian diri pada remaja akhir di Fakultas Kedokteran Universitas Udayana dengan judul penelitian "Peran Problem Focused Coping dan Konsep Diri terhadap Penyesuaian Diri pada Remaja Akhir yang Menjadi Pengurus Organisasi Kemahasiswaan di Fakultas Kedokteran Universitas Udayana" 


\section{PERAN PROBLEM FOCUSED COPING DAN KONSEP DIRI TERHADAP PENYESUAIAN DIRI REMAJA AKHIR PENGURUS ORGANISASI KEMAHASISWAAN DI FAKULTAS KEDOKTERAN UNIVERSITAS UDAYANA}

\section{METODE PENELITIAN}

\section{Variabel dan Definisi Operasional}

Variabel tergantung dalam penelitian ini adalah penyesuaian diri serta variabel bebas dalam penelitian ini adalah problem focused coping dan konsep diri. Definisi operasional dari masing-masing variabel penelitian adalah sebagai berikut:

1. Problem Focused Coping

Problem focused coping merupakan suatu usaha untuk mengelola masalah yang dihadapi dengan cara fokus terhadap permasalahan untuk mengurangi stresor, mempelajari keterampilan-keterampilan yang baru dengan melakukan confrontive coping, accepting responsibility, planful problemsolving, dan positive re-appraisal.

\section{Konsep Diri}

Konsep diri merupakan pandangan, gambaran diri, persepsi, dan penilaian keseluruhan individu mengenai diri, kemampuan, perilaku, dan kepribadian yang menjadi suatu kerangka acuan yang digunakan individu dalam berinteraksi dengan dunia.

\section{Penyesuaian Diri}

Penyesuaian diri adalah suatu usaha yang dilakukan individu secara kontinyu, yang mencakup respon mental dan tingkah laku individu sebagai usaha dalam menghadapi stres, frustrasi, dan konflik sehingga mampu mencapai harmoni pada diri sendiri dan lingkungan.

\section{Responden}

Populasi dalam penelitian ini adalah remaja akhir di Fakultas Kedokteran Universitas Udayana sebanyak 278 orang. Remaja yang dipilih menjadi subjek memiliki kriteria:

1. Berusia 18 tahun sampai 22 tahun

2. Merupakan mahasiswa Fakultas Kedokteran Universitas Udayana angkatan 2015

3. Menjadi pengurus di salah satu organisasi kemahasiswaan di Fakultas Kedokteran Universitas Udayana. Pengurus organisasi adalah mahasiswa yang terdaftar menjadi pengurus pada struktur organisasi di masing-masing organisasi kemahasiswaan yang tercantum dalam Buku Pedoman Lembaga Kemahasiswaan dan Relasi Intern (BPLKRI) Fakultas Kedokteran Universitas Udayana 2016.

Dalam penelitian ini teknik pengambilan sampel yang digunakan adalah simple random sampling. Simple random sampling adalah teknik sampling dimana pengambilan anggota sampel dari populasi dilakukan secara acak tanpa memperhatikan srata (Sugiyono, 2014). Skala yang disebarkan sebanyak 152 skala, namun dua skala tidak terisi dengan lengkap sehingga jumlah skala yang dapat dianalisis sebanyak 150 skala.

\section{Tempat Penelitian}

Penelitian dilaksanakan pada bulan Oktober 2016. Penelitian dilakukan dengan memberikan skala kepada subjek yang sudah dikelompokkan berdasarkan program studi. Pengisian skala dilakukan di ruang kelas masing-masing program studi di Fakultas Kedokteran Universitas Udayana

\section{Alat Ukur}

Alat ukur dalam penelitian ini menggunakan skala problem focused coping hasil modifikasi skala dari Larashati (2015) yang mengacu pada aspek problem focused coping menurut Folkman dan Lazarus (1984), skala konsep diri yang disusun berdasarkan aspek konsep diri menurut Fitts (dalam Agustiani, 2009), dan skala penyesuaian diri yang disusun berdasarkan pada aspek penyesuaian diri menurut Schneiders (1964).

Skala problem focused coping terdiri dari 21 item pernyataan, skala konsep diri terdiri dari 22 item pernyataan, dan skala penyesuaian diri terdiri dari 30 item pernyataan. Skala ini terdiri dari pernyataan positif (favorable) dan pernyataan negatif (unfavorable) dengan empat pilihan jawaban yaitu Sangat Sesuai (SS), Sesuai (S), Tidak Sesuai (TS), dan Sangat Tidak Sesuai (STS).

Uji validitas dilakukan untuk mengetahui apakah suatu skala yang akan digunakan dapat mengukur dengan akurat variabel yang akan diteliti. Menurut Azwar (2013) uji validitas dilakukan dengan seleksi pada aitem-aitem skala berdasarkan korelasi aitem-total. Koefisien korelasi aitem-total yang baik berkisar antara 0,30 sampai dengan 0,50. Apabila setelah uji coba, terjadi ketidakseimbangan jumlah aitem karena banyak aitem gugur, batas koefisien korelasi dapat diturunkan menjadi 0,25. Pada uji reliabilitas dalam penelitian ini, dilakukan dengan melihat nilai Alpha Cronbach. Menurut Azwar (2013) reliabilitas alat ukur dikategorikan cukup baik apabila memiliki nilai koefisien alpha lebih besar dari 0,60.

Uji coba alat ukur dilakukan pada subjek yang memiliki kesamaan karakteristik dengan subjek penelitian. Subjek pada uji coba alat ukur adalah remaja akhir yang berusia 18 sampai 22 tahun dan merupakan mahasiswa Fakultas Kedokteran Universitas Udayana angkatan 2015 yang menjadi pengurus organisasi kemahasiswaan di Fakultas Kedokteran Universitas Udayana yang terdiri dari Badan Eksekutif Mahasiswa (BEM), Badan Perwakilan Mahasiswa (BPM), Badan Pekerja (BP), Lembaga Pers Mahasiswa Press and Cyber Community (LPM PCYCO), Himpunan Mahasiswa Kedokteran Umum (HMKU), Himpunan Mahasiswa Ilmu Keperawatan (HMIK), Himpunan Mahasiswa Kesehatan Masyarakat (HMKM), Himpunan Mahasiswa Psikologi (HM Psikologi), Himpunan Mahasiswa Fisioterapi (HM Fisioterapi), Himpunan Mahasiswa Kedokteran Gigi (HMKG), Tim Bantuan Medis Janar Duta (TBM JD), Kelompok Ilmiah Hippocrates (KIH), Kelompok Mahasiswa Peduli AIDS (KMPA), Komunitas Mahasiswa Peduli Kanker 
(KOMPAK), serta Kelompok Mahasiswa Peduli Lingkungan (KMPL). Pada uji coba skala penelitian subjek berjumlah 100 orang.

Uji coba alat ukur dilakukan pada tanggal 19 September 2016, 20 September 2016, dan tanggal 21 September 2016. Skala yang tersebar sebanyak 100 skala, namun hanya 94 skala yang memenuhi syarat untuk diteliti.

Uji validitas skala problem focused coping menghasilkan 21 aitem valid dengan nilai koefisien korelasi aitem-total yang valid berkisar antara 0,338-0,613. Hasil uji reliabilitas skala problem focused coping menggunakan Alpha Cronbach menunjukkan koefisien Alpha $(\alpha)$ adalah 0,820. Koefisien alpha $(\alpha)$ sebesar 0,820 berarti bahwa skala problem focused coping mampu mencerminkan $82,0 \%$ variasi skor murni subyek. Hasil uji reliabilitas yang didapat menggambarkan skala problem focused coping dapat digunakan untuk mengukur taraf problem focused coping.

Uji validitas skala konsep diri yang telah dilakukan menghasilkan 22 aitem valid dengan nilai koefisien korelasi aitem-total yang valid berkisar antara 0,257 - 0,531. Hasil uji reliabilitas skala konsep diri menggunakan Alpha Cronbach menunjukkan koefisien Alpha $(\alpha)$ adalah 0,797. Koefisien alpha $(\alpha)$ sebesar 0,797 berarti bahwa skala konsep diri mampu mencerminkan $79,7 \%$ variasi skor murni subyek. Hasil uji reliabilitas yang didapat menggambarkan skala konsep diri dapat digunakan untuk mengukur taraf konsep diri.

Uji validitas skala penyesuaian diri menghasilkan 30 aitem valid dengan nilai koefisien korelasi aitem-total yang valid berkisar antara 0,263 - 0,496. Hasil uji reliabilitas skala penyesuaian diri menggunakan Alpha Cronbach menunjukkan koefisien Alpha $(\alpha)$ adalah 0,843 . Koefisien alpha $(\alpha)$ sebesar 0,843 berarti bahwa skala penyesuaian diri mampu mencerminkan $84,3 \%$ variasi skor murni subyek. Hasil uji reliabilitas yang didapat menggambarkan skala penyesuaian diri dapat digunakan untuk mengukur taraf penyesuaian diri.

\section{Teknik Analisis Data}

Dalam uji hipotesis penelitian, uji yang digunakan untuk menguji hipotesis dalam penelitian ini adalah regresi berganda. Sebelum melakukan uji regresi berganda, dilakukan uji normalitas, uji linieritas, serta uji multikolinieritas. Ketiga uji asumsi tersebut dilakukan dengan bantuan program SPSS 20.0 for Windows. Setelah uji asumsi terpenuhi, dilakukan uji regresi berganda dengan bantuan SPSS 20.0 for Windows dengan melihat koefisien regresi (R), uji F, dan koefisien beta.

\section{HASIL PENELITIAN}

\section{Karakteristik Subjek}

Subjek penelitian sebanyak 150 orang merupakan mahasiswa Fakultas Kedokteran Universitas Udayana angkatan 2015 dan terdaftar sebagai pengurus organisasi mahasiswa serta berasal dari seluruh program studi di Fakultas
Kedokteran Universitas Udayana. Berdasarkan jenis kelamin, sebanyak 40 orang $(26,67 \%)$ subjek penelitian merupakan laki-laki dan 110 orang $(73,33 \%)$ merupakan perempuan. Berdasarkan usia, subjek penelitian berada pada rentang usia 18 tahun sampai dengan 22 tahun dengan mayoritas subjek berusia 19 tahun sebanyak 106 orang (70,66\%). Berdasarkan pengalaman berorganisasi, mayoritas subjek memiliki pengalaman berorganisasi sebelum masuk perguruan tinggi sebanyak 92 orang $(61,33 \%)$. Berdasarkan jumlah organisasi yang diikuti, mayoritas subjek mengikuti satu organisasi kemahasiswaan sebanyak 111 orang $(74 \%)$.

\section{Deskripsi Data Penelitian}

Hasil deskripsi penelitian variabel problem focused coping, konsep diri, dan penyesuaian diri dapat dilihat pada tabel 1 .

\begin{tabular}{lcccccccc}
\multicolumn{10}{c}{ Tabel 1 } \\
\multicolumn{10}{c}{ Deskripsi data penelitian } \\
\hline Variabel & N & $\begin{array}{c}\text { Mean } \\
\text { Teoritis }\end{array}$ & $\begin{array}{c}\text { Mean } \\
\text { Empiris }\end{array}$ & $\begin{array}{c}\text { Std } \\
\text { Deviasi } \\
\text { Teoritis }\end{array}$ & $\begin{array}{c}\text { Std } \\
\text { Deviasi } \\
\text { Empiris }\end{array}$ & $\begin{array}{c}\text { Sebaran } \\
\text { Teoritis }\end{array}$ & $\begin{array}{c}\text { Sebaran } \\
\text { Empiris }\end{array}$ & T \\
\hline PFC & 150 & 52,5 & 68,38 & 10,6 & 5,205 & $21-84$ & $55-82$ & $\begin{array}{l}37.363 \\
(\mathrm{p}=0,000)\end{array}$ \\
KD & 150 & 55 & 67,29 & 11 & 5,970 & $22-88$ & $51-85$ & $\begin{array}{l}25.206 \\
(\mathrm{p}=0,000)\end{array}$ \\
& 150 & 75 & 92,36 & 15 & 7,126 & $30-120$ & $75-114$ & $\begin{array}{l}29,836 \\
(\mathrm{p}=0,000)\end{array}$ \\
\hline
\end{tabular}

Pada tabel 1 ditunjukkan bahwa variabel problem focused coping memiliki mean teoritis sebesar 52,5 dan mean empiris sebesar 68,38 dengan perbedaan sebesar 15,88 serta nilai $\mathrm{t}$ sebesar $37.363(\mathrm{p}=0,000)$. Hal ini berarti subjek penelitian memiliki taraf problem focused coping yang tinggi karena nilai mean empiris lebih besar daripada mean teoritis $(68,38>52,5)$. Berdasarkan penyebaran frekuensi, subjek dalam penelitian ini menghasilkan rentang skor antara 55 sampai dengan 82 , serta $100 \%$ subjek memiliki skor diatas mean teoritis.

Pada tabel 1 ditunjukkan bahwa variabel konsep diri memiliki mean teoritis sebesar 55 dan mean empiris sebesar 67,29 dengan perbedaan sebesar 12,29 serta nilai t sebesar $25.206(\mathrm{p}=0,000)$. Hal ini berarti subjek penelitian memiliki taraf konsep diri yang tinggi karena nilai mean empiris lebih besar daripada mean teoritis $(67,29>55)$. Berdasarkan penyebaran frekuensi, subjek dalam penelitian ini menghasilkan rentang skor antara 51 sampai dengan 85, serta 97,33\% subjek memiliki skor diatas mean teoritis.

Pada tabel 1 ditunjukkan bahwa variabel penyesuaian diri memiliki mean teoritis sebesar 75 dan mean empiris sebesar 92,36 dengan perbedaan sebesar 17,36 serta nilai t sebesar 29,836 ( $\mathrm{p}=0,000)$. Hal ini berarti subjek penelitian memiliki taraf penyesuaian diri yang tinggi karena nilai mean empiris lebih besar daripada mean teoritis (92,36> 75). Berdasarkan penyebaran frekuensi, subjek dalam penelitian ini menghasilkan rentang skor antara 75 sampai dengan 114, serta $99,33 \%$ subjek memiliki skor diatas mean teoritis.

\section{Uji Asumsi}


Tabel 2

Uji normalitas data penelitian

\begin{tabular}{lcc}
\hline \multicolumn{1}{c}{ Variabel } & Kolmogorov-Smirnov & Asymp. Sig (2-tailed) \\
\hline Problem Focused Coping & 1,015 & 0,254 \\
Konsep Diri & 0,739 & 0,646 \\
Penyesuaian Diri & 0,950 & 0,328 \\
\hline
\end{tabular}

Uji normalitas dilakukan dengan menggunakan uji Kolmogorov-Smirnov pada program SPSS 20.0 for Windows. Data dikatakan berdistribusi normal jika nilai signifikansinya p $>0,05$. Berdasarkan hasil uji normalitas pada tabel 2, variabel problem focused coping menunjukkan nilai KolmogorovSmirnov sebesar 1,015 dengan signifikansi sebesar 0,254 $(\mathrm{p}>0,05)$. Hal ini menunjukkan bahwa data pada variabel problem focused coping berdistribusi normal. Variabel konsep diri menunjukkan nilai Kolmogorov-Smirnov sebesar 0,739 dengan signifikansi sebesar 0,646 $(\mathrm{p}>0,05)$. Hal ini menunjukkan bahwa data pada variabel konsep diri berdistribusi normal. Variabel penyesuaian diri menunjukkan nilai Kolmogorov-Smirnov sebesar 0,950 dengan signifikansi sebesar 0,328 ( $\mathrm{p}>0,05)$. Hal ini menunjukkan bahwa data pada variabel penyesuaian diri berdistribusi normal.

Tabel 3

Uji linearitas data penelitian

\begin{tabular}{lllll}
\hline & & F & Sig. \\
\hline Penyesuaian & Between group & Linearity & 99,095 & 0,000 \\
Diri*Problem & & Deviation from & 0,727 & 0,804 \\
Focused Coping & & Linearity & & \\
Penyesuaian & Between group & Linearity & 85,644 & 0,000 \\
Diri*Konsep Diri & & $\begin{array}{l}\text { Deviation from } \\
\text { Linearity }\end{array}$ & 1,544 & 0,057 \\
& & Line & \\
\hline
\end{tabular}

Uji linieritas dilakukan dengan menggunakan uji compare mean pada program SPSS 20.0 for Windows. Data dapat dikatakan memiliki hubungan yang linier apabila nilai pada Linierity $\mathrm{p}<0.05$ dan nilai signifikansi pada Deviation from Linierity $p>0.05$. Berdasarkan hasil uji linieritas data penelitian pada tabel 20, variabel penyesuaian diri dengan problem focused coping memiliki hubungan yang linier karena menghasilkan nilai Linierity sebesar $0,000(\mathrm{p}<0,05)$ dan nilai signifikasi pada Deviation form Linierity sebesar 0,804 ( $>0,05)$. Variabel penyesuaian diri dengan konsep diri juga memiliki hubungan yang linier karena menghasilkan nilai Linierity sebesar $0,000(\mathrm{p}<0,05)$ dan nilai signifikasi pada Deviation form Linierity sebesar 0,057 ( $>>0,05)$. Dari kedua hasil tersebut menunjukkan bahwa terdapat hubungan yang linier antara penyesuaian diri dengan problem focused coping dan konsep diri

\begin{tabular}{lccl}
\multicolumn{4}{c}{ Tabel 4 } \\
Uji multikolinearitas data penelitian \\
\hline Variabel & Tolerance & $\begin{array}{c}\text { Variance Inflation } \\
\text { Factor }(\text { VIF })\end{array}$ & Keterangan \\
\hline Problem Focused Coping & 0,816 & 1,226 & $\begin{array}{l}\text { Tidak ada } \\
\text { multikolinieritas }\end{array}$ \\
Konsep Diri & 0,816 & 1,226 & $\begin{array}{l}\text { Tidak ada } \\
\text { multikolinieritas }\end{array}$ \\
\hline a. & &
\end{tabular}

Uji multikolinieritas digunakan untuk melihat hubungan antara variabel bebas (Yudiaatmaja, 2013). Multikolinieritas terjadi apabila koefisien korelasi antara variabel bebas tinggi. Uji multikolinieritas dilakukan dengan bantuan program SPSS 20.0 for Windows. Data dapat dikatakan tidak memiliki multikolinieritas ketika nilai VIF yang dibawah 10 dan nilai Collinierity Tolerance diatas 0,1 . Berdasarkan hasil uji multikolinieritas data penelitian pada tabel 21, variabel bebas dalam penelitian ini yaitu problem focused coping dan konsep diri dapat dikatakan tidak terjadi multikolinieritas. Hal ini ditunjukkan dengan nilai VIF sebesar 1,226 (dibawah 10) dan nilai Collinierity Tolerance 0,816 (diatas 0,1).

Berdasarkan uji normalitas, uji linearitas, dan uji multikolinearitas yang telah dilakukan maka dapat dikatakan data dalam penelitian ini berdistribusi normal, menunjukkan hubungan yang linear, dan tidak ada multikolinearitas sehingga dapat dilanjutkan ke tahap berikutnya yaitu analisis regresi berganda.

\section{Uji Hipotesis}

Hasil uji regresi berganda variabel problem focused coping dan konsep diri terhadap penyesuaian diri adalah sebagai berikut:

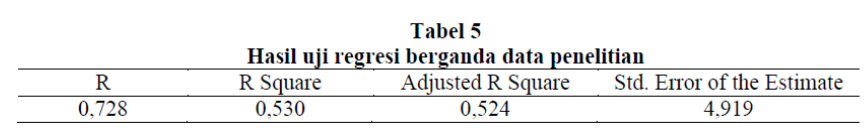

Pada tabel 5, dapat dilihat bahwa terdapat nilai $\mathrm{R}$ yang merupakan koefisien regresi sebesar 0,728 dan nilai $\mathrm{R} 2$ yang merupakan koefisien determinasi sebesar 0,530, R2 diperoleh dari mengkuadratkan nilai R. Koefisien determinasi menunjukkan besarnya peran atau sumbangan dari variabel bebas terhadap variabel tergantung. Berdasarkan hasil uji regresi berganda antara variabel bebas dan tergantung yang ditunjukkan pada tabel 22, dapat disimpulkan bahwa problem focused coping dan konsep diri secara bersama-sama memberikan sumbangan dan menentukan taraf penyesuaian diri sebesar 53\%, sedangkan $47 \%$ ditentukan oleh faktorfaktor lain yang tidak diteliti dalam penelitian ini.

Tabel 6

\begin{tabular}{lccccc}
\multicolumn{7}{c}{ Hasil uji regresi berganda signifikansi F } \\
\hline & Sum of Squares & df & Mean Square & F & Sig \\
\hline Regression & 4010.110 & 2 & 2005.055 & 82.876 & 0.000 \\
Residual & 3556.450 & 147 & 24.194 & & \\
\hline Total & 7566.560 & 149 & & & \\
\hline
\end{tabular}

Tabel 6 dapat dilihat nilai signifikansi $F$ yang dihasilkan dari hasil uji regresi berganda sebesar 0,000 $(\mathrm{p}<0,05)$. Hal ini berarti model regresi dalam penelitian ini dapat digunakan untuk memprediksi penyesuaian diri, sehingga dapat dijelaskan bahwa problem focused coping dan konsep diri secara bersama-sama berperan terhadap penyesuaian diri 
Tabel 7

Hasil Uji Regresi Berganda Nilai Koefisien Beta dan Nilai T Variabel Self Regulated Learning

\begin{tabular}{lcccccc}
\multicolumn{5}{c}{ dan Konsep Diri Terhadap Prestasi Akademik } \\
\hline \multirow{2}{*}{ Model } & \multicolumn{2}{c}{$\begin{array}{c}\text { Unstandardized } \\
\text { Coefficients }\end{array}$} & $\begin{array}{c}\text { Standardized } \\
\text { Coefficients }\end{array}$ & \multirow{2}{*}{ S } & \multirow{2}{*}{ Sig. } \\
\cline { 2 - 5 } & $\mathbf{B}$ & \multicolumn{1}{c}{ Std. Error } & Beta & & \\
\hline (Constant) & 17,013 & 5,874 & & 2,897 & 0,004 \\
\hline Problem Focused Coping & 0,653 & 0,086 & 0,477 & 7,624 & 0,000 \\
Konsep Diri & 0,456 & 0,075 & 0,382 & 6,099 & 0,000 \\
\hline
\end{tabular}

Tabel 7 dapat dilihat nilai koefisien beta terstandarisasi problem focused coping lebih besar dari nilai koefisien beta terstandarisasi konsep diri. Hal ini berarti problem focused coping memiliki peran yang lebih besar terhadap penyesuaian diri dibandingkan dengan konsep diri. Problem focused coping berperan secara signifikan terhadap penyesuaian diri karena menunjukkan koefisien beta terstandarisasi sebesar 0,477, nilai $t$ sebesar 7,634, dan signifikansi $0,000(p<0,05)$. Konsep diri juga berperan secara signifikan terhadap penyesuaian diri karena menunjukkan koefisien beta terstandarisasi sebesar 0,382, nilai $\mathrm{t}$ sebesar 6,099, dan signifikansi 0,000 $(\mathrm{p}<0,05)$.

Berdasarkan hasil uji regresi berganda pada tabel 7, dapat diprediksi taraf penyesuaian diri dari masing-masing subjek penelitian melalui persamaan garis regresi sebagai berikut:

Y $=17,013+0,653 \times 1+0,456 \times 2$
Keterangan:
Y: Penyesuaian Diri
X1: Problem Focused Coping
X2: Konsep Diri

a. Konstanta sebesar 17,013 menyatakan jika tidak ada penambahan atau peningkatan skor pada problem focused coping maupun konsep diri maka taraf penyesuaian diri sebesar 17,013.

b. Koefisien regresi X1 sebesar 0,653 menyatakan setiap penambahan atau peningkatan satuan skor subjek pada variabel problem focused coping, maka akan terjadi kenaikan taraf penyesuaian diri sebesar 0,653 .

c. Koefisien regresi X2 sebesar 0,456 menyatakan setiap penambahan atau peningkatan satuan skor subjek pada variabel konsep diri, maka akan terjadi kenaikan taraf penyesuaian diri sebesar 0,456 .

Dari hasil uji regresi berganda yang telah dihasilkan, makan rangkuman hipotesis mayor dan hipotesis minor penelitian ini dapat dilihat pada tabel 8 .

\section{Tabel 8}

Rangkuman hasil uji hipotesis penelitian

\begin{tabular}{|c|c|c|}
\hline \multicolumn{3}{|c|}{ Rangkuman hasil uji hipotesis penelitian } \\
\hline No & Hipotesis & Hasil \\
\hline 1 & $\begin{array}{l}\text { Hipotesis Mayor: } \\
\text { Problem focused coping dan konsep diri berperan terhadap } \\
\text { penyesuaian diri pada remaja akhir yang menjadi pengurus } \\
\text { organisasi kemahasiswaan di Fakultas Kedokteran Universitas } \\
\text { Udayana }\end{array}$ & Diterima \\
\hline 2 & $\begin{array}{l}\text { Hipotesis Minor: } \\
\text { a. Problem focused coping berperan terhadap penyesuaian diri } \\
\text { pada remaja akhir yang menjadi pengurus organisasi } \\
\text { kemahasiswaan di Fakultas Kedokteran Universitas Udayana }\end{array}$ & Diterima \\
\hline & $\begin{array}{l}\text { b. Konsep diri berperan terhadap penyesuaian diri pada remaja } \\
\text { akhir yang menjadi pengurus organisasi kemahasiswaan di } \\
\text { Fakultas Kedokteran Universitas Udayana }\end{array}$ & Diterima \\
\hline
\end{tabular}

\section{PEMBAHASAN DAN KESIMPULAN}

Berdasarkan hasil penelitian yang telah dijabarkan diatas, dapat disampaikan bahwa hipotesis mayor penelitian ini yaitu problem focused coping dan konsep diri berperan terhadap penyesuaian diri pada remaja akhir yang menjadi pengurus organisasi kemahasiswaan di Fakultas Kedokteran Universitas Udayana diterima.

Dari hasil uji regresi berganda, peran problem focused coping dan konsep diri dapat dilihat dari koefisien regresi sebesar 0,728 , dan nilai $\mathrm{F}$ sebesar 82,876 dengan signifikansi sebesar 0,000. Koefisien determinasi yang diperoleh adalah 0,530 yang berarti problem focused coping dan konsep diri secara bersama-sama memiliki sumbangan efektif sebesar 53\% terhadap penyesuaian diri. Dari hasil tersebut dapat disimpulkan bahwa problem focused coping dan konsep diri memiliki peran terhadap penyesuaian diri pada remaja akhir yang menjadi pengurus organisasi kemahasiswaan di Fakultas Kedokteran Universitas Udayana sebesar $53 \%$, sedangkan $47 \%$ penyesuaian diri ditentukan oleh variabel lain yang tidak diteliti dalam penelitian ini.

Remaja akhir khususnya mahasiswa yang menggunakan problem focused coping sebagai strategi penyelesaian masalah memengaruhi penyesuaian diri dari remaja itu sendiri, hal ini dikarenakan dengan strategi problem focused coping remaja terbiasa untuk melakukan analisis pada masalah yang dihadapi sehingga memiliki target-target yang terarah untuk menyelesaikan masalah langsung pada sumber penyebab masalah, dan dengan mekanisme rasionalisasi seminimal mungkin.

Hasil analisis menunjukkan bahwa problem focused coping memiliki nilai koefisien beta terstandarisasi sebesar 0,477 dan nilai $\mathrm{t}$ sebesar 7,634 dengan signifikansi sebesar 0,000. Hal ini berarti problem focused coping memiliki peran yang siginifikan terhadap penyesuaian diri pada remaja akhir yang menjadi pengurus organisasi kemahasiswaan di Fakultas Kedokteran Universitas Udayana. Individu dengan taraf problem focused coping tinggi terbiasa menganalisis suatu permasalahan sehingga dapat menemukan pilihan-pilihan penyelesaian masalah lebih banyak yang dapat digunakan sebagai perencanaan untuk penyelesaian masalah yang dihadapi. Oleh karena itu individu dengan taraf problem focused coping tinggi kemungkinan besar akan memiliki ambang stres yang tinggi karena terbiasa mengatasi kondisi stres langsung dari sumber permasalahan. Hal ini sejalan dengan hasil penelitian Bakhtiar dan Asriani (2015) yang menunjukkan bahwa strategi problem focused coping efektif dalam meningkatkan pengelolaan stress.

Ketika menggunakan strategi problem focused coping, individu mengekspresikan perasaan secara langsung terhadap sesuatu peristiwa atau terhadap individu yang menimbulkan stres. Kontrol emosi yang baik dan tidak adanya 
emosi yang berlebihan pada diri individu memungkinkan untuk individu mampu berpikir jernih sehingga mendukung munculnya berbagai pilihan-pilihan penyelesaian masalah ketika mengalami hambatan. Menurut Ali \& Asrori (2012) remaja akhir yang mencapai kematangan emosi mampu mengatasi dan mengungkapkan emosi secara tepat ketika menghadapi individu atau situasi yang memicu emosi.

Dalam penyelesaian masalah individu dengan strategi problem focused coping akan berusaha untuk membuat kondisi masalah yang dihadapi kembali stabil dengan cara introspeksi diri dan dengan melakukan sesuatu untuk memperbaiki masalah sehingga tidak terulang kembali. Folkman dan Lazarus (1984) mengemukakan bahwa perilaku tersebut menunjukkan bahwa cara yang dilakukan adalah dengan meminimalkan mekanisme pertahanan diri yang dimiliki individu. Mekanisme pertahanan diri yang minimal merupakan kriteria penyesuaian diri yang baik. Dari hal tersebut ditekankan bahwa individu dengan problem focused coping melakukan suatu hal dalam bentuk perilaku untuk menyelesaikan masalah, tidak sekedar rasionalisasi tanpa penyelesaian masalah.

Setelah memahami masalah dan berusaha untuk menstabilkan kondisi diri, individu dengan problem focused coping tinggi akan melakukan analisis untuk melakukan pemecahan masalah dalam mengatasi kondisi stres, memahami masalah, serta membuat perencanaan perilaku sebagai solusi untuk mengatasi masalah. Adanya perencanaan penyelesaian masalah erat kaitannya dengan kemampuan mengarahkan diri. Dalam mengarahkan diri untuk berfokus pada masalah juga diperlukan cara berpikir yang rasional. Selain itu kemampuan berpikir rasional dan mengarahkan diri juga perlu diikuti dengan sikap yang realistis dan objektif dalam melihat masalah secara nyata dan objektif, sehingga individu dapat lebih terfokus pada penyebab masalah dan semakin mudah untuk menemukan penyelesaian masalah. Menurut Schneiders (1964) berpikir rasional, mengarahkan diri, serta sikap yang realistis dan objektif merupakan tolak ukur bagi penyesuaian diri yang normal. Hal tersebut berkaitan dengan dimensi planful problem-solving dalam problem focused coping sebagai salah satu strategi pemecahan masalah bagi individu.

Hal terpenting dari penggunaan strategi problem focused coping adalah adanya kemampuan individu untuk menumbuhkan makna positif dan mengembangkan diri menjadi lebih baik. Pengalaman individu selama penyelesaian masalah digunakan sebagai bahan pembelajaran agar tidak terulang lagi masalah yang sama (Lazarus, 1969). Kemampuan untuk belajar dan memanfaatkan pengalaman masa lalu individu berkaitan dengan bagaimana individu menumbuhkan makna positif dalam penyelesaian masalah dengan strategi problem focused coping.
Masa remaja merupakan masa untuk mengumpulkan berbagai pengalaman dalam hidup. Pengalaman-pengalaman tersebut secara tidak langsung akan memengaruhi konsep diri seseorang karena individu dapat semakin mengenali diri melalui pengalaman-pengalaman hidup yang telah dilewati (Burns, 1993). Salah satu pengalaman yang dilewati individu misalkan menjadi bagian dari suatu kelompok atau organisasi.

Hasil analisis menunjukkan bahwa konsep diri memiliki nilai koefisien beta terstandarisasi sebesar 0,382 dan nilai t sebesar 6,099 dengan signifikansi sebesar 0,000. Hal ini berarti konsep diri memiliki peran yang signifikan terhadap penyesuaian diri pada remaja akhir yang menjadi pengurus organisasi kemahasiswaan di Fakultas Kedokteran Universitas Udayana. Individu dengan taraf konsep diri yang tinggi berarti konsep diri semakin positif. Hal ini sejalan dengan hasil penelitian Nurhadi (2013) yang menyebutkan bahwa terdapat hubungan signifikan antara konsep diri positif dengan penyesuaian diri remaja. Konsep diri yang positif tentu saja dipengaruhi oleh pengalaman-pengalaman positif yang dialami oleh remaja dalam hidup. Menjadi bagian dari suatu kelompok bergengsi, berhasil melewati seleksi menjadi pengurus suatu organisasi, memiliki pengalaman untuk berperan dalam suatu kegiatan, akan menumbuhkan makna positif bagi individu mengenai diri.

Kemampuan individu mengenali diri secara sadar sehingga mampu untuk mengharmoniskan diri dengan lingkungan memengaruhi bagaimana individu dalam menyesuaikan diri. Menurut Rogers (dalam King, 2014), seseorang yang memiliki konsep diri tidak akurat cenderung tidak dapat menyesuaikan diri. Dalam penyesuaian diri yang baik dibutuhkan kemampuan mengarahkan diri, baik untuk berperilaku yang tepat, rasional, berpikir realistis dan objektif. Kemampuan ini berkaitan erat dengan konsep diri yang dimiliki oleh seseorang, yang telah dibentuk oleh individu dan menjadi kerangka dalam menyesuaikan diri dengan lingkungan. Anissa \& Handayani (2012) menyatakan bahwa konsep diri yang dimiliki individu memberikan pengaruh terhadap proses berpikir, perasaan, keinginan, nilai maupun tujuan hidup seseorang sehingga memiliki penyesuaian diri yang lebih baik.

Konsep diri positif terbentuk ketika individu merasa bahwa diri berharga, kompeten dan percaya diri. Perasaan ini meningkatkan perasaan berharga sehingga berkontribusi untuk mengurangi frustrasi. Mampu mengurangi rasa frustrasi merupakan salah satu indikator penyesuaian diri yang baik. Selain itu adanya kemampuan untuk memodifikasi nilai-nilai dan prinsip-prinsip hidup sesuai dengan pengalaman baru yang didapatkan berkaitan dengan kemampuan individu untuk belajar, dengan belajar dari pengalaman individu menemukan nilai-nilai yang positif sehingga memberikan kontribusi untuk menciptakan konsep diri yang positif pula (Schneiders, 1964; Folkman \& Lazarus, 1984). Hal ini sejalan dengan hasil 
penelitian Astuti (2015) yang menyatakan bahwa konsep diri positif dan penyesuaian diri memiliki korelasi yang kuat, sehingga semakin tinggi konsep diri positif maka semakin tinggi taraf penyesuaian diri.

Individu dengan konsep diri positif tidak memiliki kekhawatiran terhadap masa lalu dan masa yang akan datang. Hal ini berkaitan dengan memanfaatkan pengalaman masa lalu dan sikap realistis serta objektif. Tidak adanya kekhawatiran pada masa lalu dapat muncul karena individu dapat memanfaatkan pengalaman masa lalu sebagai pembelajaran dalam menyesuaian diri pada masa sekarang. Sedangkan tidak adanya kekhawatiran pada masa yang akan datang dapat muncul karena individu bersikap realistis dan objektif dalam menghadapi masalah, dapat menerima kenyataan yang dialami sebagai bentuk dari penyesuaian diri yang baik. Dapat menerima diri dan evaluasi diri yang positif merupakan ciri dari individu dengan konsep diri yang positif. Sikap realistis ditunjukkan dengan menerima kenyataan yang dialami tanpa konflik dan melihatnya secara objektif. Individu akan lebih mudah memberikan evaluasi bagi diri sendiri secara positif, dengan adanya penerimaan diri dan evaluasi diri yang positif maka akan menciptakan keharmonisan dalam diri individu sehingga memiliki penyesuaian diri yang baik. Berdasarkan pemarapan yang disampaikan diatas, dapat disimpulkan bahwa pada masa remaja akhir peran penggunaan strategi problem focused coping dan konsep diri yang positif bersama-sama akan memengaruhi penyesuaian diri individu.

Hasil deskripsi statistik data penelitian menunjukkan taraf problem focused coping mayoritas subjek penelitian tergolong tinggi yaitu sebesar $52,7 \%$. Tingginya taraf problem focused coping pada remaja akhir yang menjadi pengurus organisasi kemahasiswaan di Fakultas Kedokteran Universitas Udayana dipengaruhi oleh keterlibatan dan peran pengurus organisasi dalam menjalankan tugas selama satu periode kepengurusan. Menjadi pengurus organisasi berarti menjadi bagian dari masalah yang dialami oleh organisasi selama satu periode kepengurusan. Hal ini menjadikan pengurus organisasi terbiasa untuk dihadapkan pada masalah-masalah yang beragam diluar masalah akademik selama satu periode kepengurusan. Masalah organisasi tentu saja membutuhkan penyelesaian yang berbeda dengan masalah pribadi karena menyangkut pada pemikiran lebih dari satu orang (Saragih, 2015). Terbiasa untuk menganalisis masalah bersama-sama, akan menjadikan pengurus organisasi memiliki target-target penyelesaian masalah yang beragam serta lebih terarah. Selain itu, pengalaman berorganisasi sebelum menjadi mahasiswa dan pengalaman dalam kegiatan kepanitiaan juga dapat memengaruhi tingginya tingkat problem focused coping pada pengurus organisasi. Hal ini dikarenakan pengurus organisasi akan menggunakan pengalaman berorganisasi untuk menyelesaikan masalah serupa yang dihadapi selama menjadi pengurus organisasi (Folkman \& Lazarus, 1984). Data penelitian menunjukkan, 61,33\% subjek penelitian ini sudah memiliki pengalaman berorganisasi sebelumnya, sehingga memiliki peran terhadap problem focused coping yang tinggi.

Hasil deskripsi statistik data penelitian menunjukkan taraf konsep diri mayoritas subjek penelitian tergolong tinggi yaitu sebesar $65,3 \%$. Tingginya taraf konsep diri pada remaja akhir yang menjadi pengurus organisasi kemahasiswaan di Fakultas Kedokteran Universitas Udayana dipengaruhi oleh pengalaman berorganisasi yang telah dimiliki sebelumnya. Pengalaman organisasi di bangku SMA menjadi nilai lebih pada pengurus organisasi untuk membentuk konsep diri yang positif mengenai diri. Semakin positif konsep diri seseorang berarti individu tersebut semakin mengenali diri (Burns, 1993). Melalui pengalaman organisasi, pengurus organisasi memiliki kesempatan untuk mengikuti kegiatan diluar perkuliahan lebih banyak dibandingkan mahasiswa yang bukan merupakan pengurus organisasi. Pengalamanpengalaman yang diperoleh diluar perkuliahan dapat memberikan gambaran bagi pengurus organisasi untuk semakin mengetahui minat, kemampuan, sehingga semakin mengenali diri sendiri. Individu yang sudah mampu mengenali diri sendiri dengan baik akan mampu mengharmoniskan diri dengan lingkungan, sehingga mampu menyesuaikan diri dengan baik. Pengalaman berhasil melewati serangkaian tahap seleksi untuk menjadi seorang pengurus organisasi juga dapat memengaruhi konsep diri positif pada pengurus organisasi. Pengalaman positif tersebut dapat menumbuhkan rasa kompeten, rasa percaya diri, dan menumbuhkan makna positif pada diri pengurus organisasi karena sudah berhasil melewati tahapan seleksi menjadi pengurus diantara mahasiswa lain yang juga mendaftarkan diri menjadi pengurus organisasi (Wijaya \& Pratitis, 2012).

Hasil deskripsi statistik data penelitian menunjukkan taraf penyesuaian diri mayoritas subjek penelitian tergolong tinggi yaitu sebesar $74,7 \%$. Tingginya taraf penyesuaian diri pada remaja akhir yang menjadi pengurus organisasi kemahasiswaan di Fakultas Kedokteran Universitas Udayana dipengaruhi oleh tingginya taraf problem focused coping dan tingginya taraf konsep diri yang dimiliki pada remaja akhir yang menjadi pengurus organisasi kemahasiswaan di Fakultas Kedokteran Universitas Udayana. Hal ini ditunjukkan pada hasil uji regresi berganda penelitian yaitu problem focused coping dan konsep diri secara bersama-sama berperan terhadap penyesuaian diri.

Pada hasil uji regresi berganda koefisien beta terstandarisasi problem focused coping lebih besar dari nilai koefisien beta terstandarisasi konsep diri. Hal ini berarti problem focused coping memiliki peran yang lebih besar terhadap penyesuaian diri dibandingkan dengan konsep diri. Aspek problem focused coping terutama aspek planful problem solving sangat berkaitan dengan aspek penyesuaian diri. Ketika individu menyesuaikan diri, dibutuhkan adanya 
sikap meminimalkan mekanisme pertahanan diri seperti rasionalisasi serta mampu berpikir rasional dan mampu mengarahkan diri. Individu dengan problem focused coping yang tinggi akan mampu untuk mengatasi kondisi stres dengan bersikap tenang dan berfokus terhadap masalah sehingga penyelesaian masalah akan lebih terarah serta mekanisme pertahanan diri dapat diminimalisir (Lazarus, 1969). Ketika permasalahan sudah dapat terselesaikan dengan baik, maka individu dapat dengan mudah untuk menyelaraskan diri dengan lingkungan, sehingga tercapai kondisi yang harmonis antara diri dengan lingkungan yang menandakan individu tersebut memiliki penyesuaian diri yang baik (Schneiders, 1964). Pada remaja pengurus organisasi misalnya, ketika remaja menggunakan strategi problem focused coping, maka remaja akan melakukan analisis permasalahan dan merencakan strategi pemecahan masalah yang lebih terarah. Hal ini menjadikan remaja pengurus organisasi lebih mudah untuk menyesuaikan diri karena masalah terselesaikan dan harmoni antara diri dan lingkungan sekitar tercapai dengan baik.

Kegiatan kepanitiaan juga memengaruhi subjek penelitian ini memiliki penyesuaian diri yang baik. Kegiatan kepanitiaan yang diadakan oleh seluruh organisasi kemahasiswaan di Fakultas Kedokteran Universitas Udayana berjumlah lebih dari 100 kegiatan dalam satu tahun (BEM FK Unud, 2016). Selama kegiatan kepanitiaan, tentu pengurus akan berinteraksi satu sama lain dengan sesama pengurus maupun mahasiswa yang tidak menjadi pengurus dalam menyelesaikan masalah-masalah yang terjadi. Pengalaman menjadi bagian dari suatu kepanitiaan menjadikan pengurus organisasi terbiasa melakukan analisis terhadap berbagai macam masalah sehingga akan terbiasa untuk memiliki targettarget yang terarah dalam menyelesaikan masalah. Hal ini akan memengaruhi taraf problem focused coping dari pengurus organisasi yang secara tidak langsung akan memengaruhi penyesuaian diri remaja pengurus organisasi.

Ketika mengikuti kepanitiaan, seorang pengurus organisasi akan dipertemukan dengan mahasiswa dari berbagai program studi di Fakultas Kedokteran Universitas Udayana. Interaksi dengan mahasiswa dari program studi yang berbedabeda akan memberikan kesempatan bagi pengurus organisasi untuk saling mengenal dan berkumpul. Semakin sering berinteraksi dengan orang banyak, tingkat percaya diri pengurus organisasi akan semakin meningkat (Astuti, 2015). Hal ini akan memberikan pengaruh positif pada konsep diri dari pengurus organisasi tersebut.

Berdasarkan hasil data penelitian, maka problem focused coping dan konsep diri yang tinggi pada remaja akhir yang menjadi pengurus organisasi kemahasiswaa di Fakultas Kedokteran Universitas Udayana perlu untuk dipertahankan. Hal tersebut dapat membantu remaja akhir yang menjadi pengurus organisasi kemahasiswaan untuk lebih mudah menyesuaikan diri.

Keterbatasan yang dimiliki peneliti dalam penelitian ini adalah sulitnya melakukan kategorisasi jenis organisasi yang pernah diikuti sebelumnya karena subjek tidak mengisi dengan lengkap organisasi apa yang diikuti sebelumnya. Hal tersebut menjadikan peneliti hanya melakukan kategorisasi subjek berdasarkan pengalaman berorganisasi sebelumnya. Keterbatasan penelitian lainnya adalah jumlah subjek yang mengikuti organisasi lebih dari satu organisasi sedikit, sehingga menjadi keterbatasan penelitian karena tidak dapat dilakukan uji beda antara subjek yang mengikuti satu organisasi dengan yang mengikuti lebih dari satu organisasi kemahasiswaan di Fakultas Kedokteran Universitas Udayana.

Setelah melakukan serangkaian prosedur analisis data penelitian, karya tulis ini telah mencapai tujuan penelitian yaitu mengetahui peran problem focused coping dan konsep diri terhadap penyesuaian diri pada remaja akhir yang menjadi pengurus organisasi kemahasiswaan di Fakultas Kedokteran Universitas Udayana.

Berdasarkan hasil penelitian dan analisis data yang dilakukan, maka diperoleh kesimpulan problem focused coping dan konsep diri secara bersama-sama berperan terhadap penyesuaian diri pada remaja akhir yang menjadi pengurus organisasi kemahasiswaan di Fakultas Kedokteran Universitas Udayana, problem focused coping berperan terhadap penyesuaian diri pada remaja akhir yang menjadi pengurus organisasi kemahasiswaan di Fakultas Kedokteran Universitas Udayana, konsep diri berperan terhadap penyesuaian diri pada remaja akhir yang menjadi pengurus organisasi kemahasiswaan di Fakultas Kedokteran Universitas Udayana, problem focused coping pada remaja akhir yang menjadi pengurus organisasi kemahasiswaan di Fakultas Kedokteran Universitas Udayana tergolong tinggi, karena mayoritas subjek memiliki taraf problem focused coping yang tinggi yaitu sebesar 52,7\%, konsep diri pada remaja akhir yang menjadi pengurus organisasi kemahasiswaan di Fakultas Kedokteran Universitas Udayana tergolong tinggi, karena mayoritas subjek memiliki konsep diri yang tinggi yaitu sebesar 65,3\%, serta Penyesuaian diri remaja akhir yang menjadi pengurus organisasi kemahasiswaan di Fakultas Kedokteran Universitas Udayana tergolong tinggi, karena mayoritas subjek memiliki penyesuaian diri yang tinggi yaitu sebesar 74,7\%.

Berdasarkan kesimpulan yang diperoleh, maka dapat disampaikan beberapa saran praktis bagi pihak-pihak terkait. Bagi remaja akhir yang menjadi pengurus organisasi kemahasiswaan, diharapkan mampu untuk memahami sumber permasalahan sehingga dapat dipilih penggunaan strategi coping yang tepat sesuai dengan konteks permasalahan. Permasalahan yang dapat diselesaikan dengan penggunaan problem focused coping dapat terwujud dengan berfokus pada 
masalah yang dihadapi serta meminimalisi rasionalisasi diri saat menyelesaikan masalah. Strategi problem focused coping juga dapat dilakukan dengan membuat target-target penyelesaian masalah, sehingga penyelesaian masalah dapat dilakukan dengan lebih terarah. Terbiasa untuk terarah dalam menyelesaikan masalah di organisasi juga dapat diaplikasikan dalam bidang akademik dan kehidupan sehari-hari. Dalam kehidupan akademik sebagai mahasiswa, dapat dilakukan dengan membuat target pencapaian akademik, membuat skala prioritas untuk deadline tugas dengan kegiatan kepanitiaan, serta kritis dalam berkegiatan yang memiliki tujuan yang jelas. Dalam kehidupan sehari-hari, dapat dilakukan dengan membedakan permasalahan sesuai dengan konteks lingkungan seperti masalah di rumah, masalah di bidang akademik, dan masalah di organisasi. Remaja diharapkan mampu untuk mempertahankan konsep diri yang positif, karena konsep diri yang tinggi berperan terhadap penyesuaian diri. Hal ini dapat dilakukan dengan mengikuti berbagai macam kegiatan yang menantang dan beragam baik kegiatan kemahasiswaan maupun kegiatan akademik. Hal tersebut dapat memperkayaan pengalaman sehingga berperan terhadap konsep diri yang positif.

Saran bagi orangtua diharapkan dapat memberikan perlakuan yang dapat mempertahankan penggunaan strategi problem focused coping pada remaja. Hal itu dapat dilakukan melalui pola asuh dengan memberikan anak contoh bagaimana penyelesaian masalah yang terarah tanpa rasionalisasi yang berlebihan, terbiasa untuk mengajak anak membicarakan dan menganalisis masalah yang terjadi di keluarga maupun yang dialami remaja itu sendiri. Hal ini perlu dilakukan karena penggunaan problem focused coping berperan terhadap penyesuaian diri remaja pengurus organisasi. Orangtua diharapkan dapat memberikan perhatian dan dukungan terhadap kegiatan-kegiatan yang diikuti oleh remaja pengurus organisasi. Hal ini penting dilakukan sebagai kontrol agar tidak terbiasa mengambil kegiatan berlebihan tanpa ada tujuan yang jelas. Arahkan remaja pada kegiatan-kegiatan positif dengan tetap memberikan kesempatan pada remaja untuk memutuskan kegiatan yang akan dilakukan. Hal ini dapat dilakukan sedini mungkin mulai dari masa kanak-kanak, karena pengalaman-pengalaman yang positif berkontribusi untuk membangun rasa keberhargaan, rasa kompeten dan percaya diri sehingga remaja pengurus organisasi memiliki pandangan yang positif mengenai diri.

Saran bagi institusi pendidikan khususnya perguruan tinggi, diharapkan institusi pendidikan dapat terus memberikan dukungan terhadap kegiatan mahasiswa diluar bidang akademik seperti organisasi kemahasiswaan. Hal ini penting sebagai media untuk mengasah kemampuan remaja diluar bidang akademik seperti kemampuan menyesuaikan diri, penggunaan problem focused coping dan pembentukan konsep diri yang positif.
Saram bagi peneliti selanjutnya pada penelitian ini, sampel yang digunakan adalah pengurus organisasi kemahasiswaan di Fakultas Kedokteran Universitas Udayana angkatan 2015, bagi peneliti selanjutnya yang ingin melakukan penelitian serupa sebaiknya melibatkan pengurus organisasi kemahasiswaan di Fakultas Kedokteran Universitas Udayana angkatan 2014, 2013, maupun angkatan yang masih aktif di organisasi kemahasiswaan. Hal ini bertujuan agar dapat diperoleh perbedaan penyesuaian diri berdasarkan perbedaan angkatan yang tentunya juga berdasarkan perbedaan waktu masa kepengurusan. Populasi dalam penelitian ini merupakan organisasi kemahasiswaan di Fakultas Kedokteran Universitas Udayana, bagi peneliti selanjutnya yang ingin melakukan penelitian serupa sebaiknya melibatkan organisasi yang lebih luas misalnya organisasi kemahasiswaan di seluruh Universitas Udayana sehingga data yang diperoleh lebih bervariasi dan representatif. Pada penelitian ini belum dilakukan uji perbedaan terhadap data pendidikan terakhir orangtua. Bagi peneliti selanjutnya yang ingin melakukan penelitian serupa, diharapkan dapat melakukan penelitian yang berkaitan dengan penyesuaian diri berdasarkan perbedaan pendidikan terakhir orangtua. Pada penelitian ini belum dilakukan uji perbedaan berasarkan jumlah organisasi yang diikuti. Bagi peneliti selanjutnya yang ingin melakukan penelitian serupa, diharapkan dapat melakukan penelitian yang berkaitan dengan penyesuaian diri berdasarkan jumlah organisasi yang diikuti. Sumbangan efektif dalam penelitian ini sebesar $53 \%$, yang berarti terdapat $47 \%$ faktor lain yang memengaruhi penyesuaian diri yang tidak diteliti dalam penelitian ini. Faktor-faktor lain seperti pola asuh, motivasi, tipe kepribadian, efikasi diri, kemandirian, kecerdasan emosional, dapat dijadikan bahan pertimbangan bagi peneliti selanjutnya yang mungkin memiliki hubungan dengan penyesuaian diri. Bagi peneliti selanjutnya dapat memperkaya data demografi seperti daerah asal, pekerjaan orangtua, dan IPK terakhir subjek dengan analisis secara kuantitatif maupun kualitatif.

\section{DAFTAR PUSTAKA}

Agustiani, H. (2009). Psikologi perkembangan: Pendekatan ekologi kaitannya dengan konsep diri dan penyesuaian diri pada remaja. Bandung: Refika Aditama.

Ali, M. \& Asrori, M. (2012). Psikologi remaja. Jakarta: Bumi Aksara. Anissa, N. \& Handayani, A. (2012). Hubungan antara konsep diri dan kematangan emosi dengan penyesuaian diri istri yang tinggal bersama keluarga suami. Jurnal Psikologi Pitutur. $1(1), 57-67$.

Astuti, A. P. (2015). Analisis hubungan konsep diri positif dengan penyesuaian diri mahasiswa FKIP Universitas Lampung angkatan 2014 yang berasal dari luar provinsi Lampung. Skripsi (tidak dipublikasi). Bandar Lampung: Fakultas Keguruan dan Ilmu Pendidikan Universitas Lampung. 


\section{PERAN PROBLEM FOCUSED COPING DAN KONSEP DIRI TERHADAP PENYESUAIAN DIRI REMAJA AKHIR PENGURUS ORGANISASI KEMAHASISWAAN DI FAKULTAS KEDOKTERAN UNIVERSITAS UDAYANA}

Atwater, E. (1983). Psychology of adjusment: Personal growth in a changing world. New Jersey: Prentice-Hall.

Azwar, S. (2014). Reliabilitas dan validitas. Yogyakarta: Pustaka Pelajar.

Badan Eksekutif Mahasiswa Fakultas Kedokteran Universitas Udayana. (2016). Buku pedoman lembaga kemahasiswaan dan relasi intern Fakultas Kedokteran Universitas Udayana. Denpasar: Departemen Dalam Negeri Badan Eksekutif Mahasiswa Fakultas Kedokteran Universitas Udayana 2016.

Bakthiar, M. I \& Asriani. (2015). Efektivitas strategi problem focused coping dan emotional focused coping dalam meningkatkan pengelolaan stres siswa di SMA Negeri 1 Barru. Jurnal Ilmu Pendidikan, Psikologi, Bimbingan dan Konseling. 5(2), 69-82.

Basuki, A. (2017, 19 Januari). Organisasi mahasiswa, menciptakan sarjana plus. Diunduh dari Jurusan Teknik Sipil UNS: sipil.ft.uns.ac.id

Burns, R. B. (1993). Konsep diri: Teori, pengukuran, perkembangan dan perilaku. (Eddy, penerjemah). Jakarta: Arcan.

Folkman, S. \& Lazarus, R. S. (1984). Stress, appraisal, and coping 1st edition. New York: Springer Publishing Company.

Gunarta, M. E. (2015). Konsep diri, dukungan sosial dan penyesuaian diri sosial mahasiswa pendatang di Bali. Persona, Jurnal Psikologi Indonesia. 4(2), 183-194.

Hurlock, E. B. (1980). Psikologi perkembangan: Suatu pendekatan sepanjang rentang kehidupan edisi kelima. (Istriwidayanti \& Soedjarwo, penerjemah). Jakarta: Erlangga.

King, L. A. (2014). Psikologi umum: Sebuah pandangan apresiatif buku 2. Jakarta: Salemba Humanika.

Larashati, M. A. P. (2015). Peran pola asuh autoritatif dan kecerdasan emosional terhadap problem focused coping pada remaja akhir di Program Studi Pendidikan Dokter FK UNUD. Skripsi (tidak dipublikasi). Denpasar: Program Studi Psikologi Fakultas Kedokteran Universitas Udayana.

Lazarus, R. S. (1969). Pattern of adjustment and human effectivenes. New York: McGraw Hill Book \& Co.

Merdeka. (2016, September 27). Pemuda dan mahasiswa bagian penting dalam gerakan revolusi mental. Diunduh dari merdeka.com: http://www.merdeka.com/peristiwa/pemudadan-mahasiswa-bagian-penting-dalam-gerakan-revolusimental

Nurhadi, R. A. (2013). Hubungan antara konsep diri dan penyesuaian diri pada remaja di Islamic Boarding School SMPIT DAARUL HIKMAH Bontang. Skripsi (tidak dipublikasi). Malang: Fakultas Pendidikan Psikologi, Universitas Negeri Malang.

Santrock, J. W. (2007). Remaja, edisi kesebelas. Jakarta: Penerbit Erlangga.

Saragih, J. H. \& Valentina, D. T. (2015). Hubungan antara kecerdasan emosional dengan prestasi akademik pada mahasiswa aktivis organisasi kemahasiswaan di lingkungan Universitas Udayana. Jurnal Psikologi Udayana. 2(2). 246255.

Sasmita, I. A. G. H. D. \& Rustika, I. M. (2015). Peran efikasi diri dan dukungan sosial teman sebaya terhadap penyesuaian diri mahasiswa tahun pertama Program Studi Pendidikan
Dokter Fakultas Kedokteran Universitas Udayana. Jurnal Psikologi Udayana. 2(2), 280-289.

Schneiders, A. A. (1964). Personal adjustment and mental health. New York: Holt, Rinehart and Winston.

Semaraputri, S.A.K.T. (2016a). Studi pendahuluan pendapat ketua organisasi mengenai pengurus organisasi angkatan $2015 \mathrm{di}$ Fakultas Kedokteran Universitas Udayana. (Naskah tidak dipublikasikan). Denpasar: Program Studi Psikologi Fakultas Kedokteran Universitas Udayana.

Semaraputri, S.A.K.T. (2016b). Studi pendahuluan pada pengurus organisasi angkatan 2015 di Fakultas Kedokteran Universitas Udayana. (Naskah tidak dipublikasikan). Denpasar: Program Studi Psikologi Fakultas Kedokteran Universitas Udayana.

Setyono, A. (2013). Pengaruh keaktifan berorganisasi dan kerajinan beribadah terhadap kematangan kepribadian pada mahasiswa PAI semester VI Sekolah Tinggi Agama Islam Negeri (STAIN) Salatiga. Skripsi (tidak dipublikasi). Program Studi Pendidikan Agama Islam Sekolah Tinggi Agama Islam Negeri (STAIN) Salatiga, Salatiga.

Silvana. (2012). Problem focused coping teori dan praktek. LPPM. Semarang.

Slavin, R. E. (2011). Psikologi pendidikan: Teori dan praktik edisi kesembilan jilid 1. Jakarta: PT Indeks.

Sugiyono. (2014). Metode penelitian kombinasi (mixed method) cetakan keenam. Bandung: Alfabeta.

Taylor, S. E. (2009). Health psychology seventh edition. Los Angeles: The McGraw-Hill Companies.

Wijaya, I. P. \& Pratitis, N. T.. (2012). Efikasi diri akademik, dukungan sosial orangtua dan penyesuaian diri mahasiswa dalam perkuliahan. Jurnal Persona. 1(1), 40-52.

Yudiaatmaja, F. (2013). Analisis regesi dengan menggunakan aplikasi komputer statistik SPSS. Jakarta: Gramedia Pustaka Utama.

Zakiyah, N., Hidayati, F.N.R., \& Setyawan, I. (2010). Hubungan antara penyesuaian diri dengan prokastinasi akademik siswa sekolah berasrama SMP N 3 Peterongan Jombang. Jurnal Psikologi Undip. 8(2), 156-166. 